\title{
Publisher Correction: A systematic review of employment outcomes from youth skills training programmes in agriculture in low- and middle-income countries
}

W. H. Eugenie Maïga (D, Mohamed Porgo (D), Pam Zahonogo, Cocou Jaurès Amegnaglo, Doubahan Adeline Coulibaly, Justin Flynn, Windinkonté Seogo, Salimata Traoré (D), Julia A. Kelly (D) and Gracian Chimwaza

Correction to: Nature Food https://doi.org/10.1038/s43016-020-00172-x, published online 12 October 2020.

This Article was originally published with an incorrect copyright status, and should have been Open Access; this has been amended and the Article is now published under a Creative Commons license CC BY 4.0.

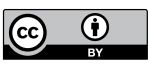

Open Access This article is licensed under a Creative Commons Attribution 4.0 International License, which permits use, sharing, adaptation, distribution and reproduction in any medium or format, as long as you give appropriate credit to the original author(s) and the source, provide a link to the Creative Commons license, and indicate if changes were made. The images or other third party material in this article are included in the article's Creative Commons license, unless indicated otherwise in a credit line to the material. If material is not included in the article's Creative Commons license and your intended use is not permitted by statutory regulation or exceeds the permitted use, you will need to obtain permission directly from the copyright holder. To view a copy of this license, visit http://creativecommons.org/licenses/ by/4.0/.

Published online: 20 October 2020

https://doi.org/10.1038/s43016-020-00183-8

(c) The Author(s) 2020 